\title{
Zinc deficiency or excess within the physiological range increases genome instability and cytotoxicity, respectively, in human oral keratinocyte cells
}

\author{
Razinah Sharif • Philip Thomas • Peter Zalewski • \\ Michael Fenech
}

Received: 16 May 2011/Accepted: 8 September 2011/Published online: 21 September 2011

(C) Springer-Verlag 2011

\begin{abstract}
Zinc ( $\mathrm{Zn})$ is an essential component of $\mathrm{Zn}$-finger proteins and acts as a cofactor for enzymes required for cellular metabolism and in the maintenance of DNA integrity. The study investigated the genotoxic and cytotoxic effects of Zn deficiency or excess in a primary human oral keratinocyte cell line and determined the optimal concentration of two $\mathrm{Zn}$ compounds ( $\mathrm{Zn}$ Sulphate $\left(\mathrm{ZnSO}_{4}\right)$ and $\mathrm{Zn}$ Carnosine $(\mathrm{ZnC})$ ) to minimise DNA damage. $Z n$-deficient medium $(0 \mu \mathrm{M})$ was produced using Chelex treatment, and the two $\mathrm{Zn}$ compounds $\mathrm{ZnSO}_{4}$ and $\mathrm{ZnC}$ were tested at concentrations of $0.0,0.4,4.0$, 16.0, 32.0 and 100.0 $\mu \mathrm{M}$. Cell viability was decreased in $\mathrm{Zn}$ depleted cells $(0 \mu \mathrm{M})$ as well as at $32 \mu \mathrm{M}$ and $100 \mu \mathrm{M}$ for both $\mathrm{Zn}$ compounds $(P<0.0001)$ as measured via the MTT assay. DNA strand breaks, as measured by the comet assay, were found to be increased in $\mathrm{Zn}$-depleted cells compared with the other treatment groups $(P<0.05)$. The Cytokinesis Block Micronucleus Cytome assay showed a significant increase in the frequency of both apoptotic and necrotic cells under $\mathrm{Zn}$-deficient conditions $(P<0.05)$. Furthermore, elevated frequencies of micronuclei $(\mathrm{MNi})$, nucleoplasmic bridges (NPBs) and nuclear buds (NBuds) were observed at 0 and $0.4 \mu \mathrm{M} \mathrm{Zn}$, whereas these biomarkers were minimised for both $\mathrm{Zn}$ compounds at 4 and $16 \mu \mathrm{M} \mathrm{Zn}(P<0.05)$,
\end{abstract}

R. Sharif $\cdot$ P. Thomas $\cdot$ M. Fenech $(\bowtie)$

CSIRO Food and Nutritional Sciences,

Adelaide, SA, Australia

e-mail: michael.fenech@csiro.au

R. Sharif · P. Zalewski

School of Medicine, Faculty of Health Sciences,

University of Adelaide, Adelaide, SA, Australia

R. Sharif

Program of Nutrition, School of Healthcare Sciences,

Faculty of Health Sciences, Universiti Kebangsaan Malaysia,

Kuala Lumpur, Malaysia suggesting these concentrations are optimal to maintain genome stability. Expression of PARP, p53 and OGG1 measured by western blotting was increased in $\mathrm{Zn}$-depleted cells indicating that DNA repair mechanisms are activated. These results suggest that maintaining $\mathrm{Zn}$ concentrations within the range of $4-16 \mu \mathrm{M}$ is essential for DNA damage prevention in cultured human oral keratinocytes.

Keywords Zinc - Cytotoxicity - DNA damage . Genomic stability · Human oral keratinocytes . Micronuclei

\begin{tabular}{|c|c|}
\hline \multicolumn{2}{|c|}{ Abbreviations } \\
\hline $\mathrm{HOK}$ & Human oral keratinocytes \\
\hline CBMN-Cyt & $\begin{array}{l}\text { Cytokinesis block micronucleus cytome } \\
\text { assay }\end{array}$ \\
\hline MTT & $\begin{array}{l}\text { (3-(4,5-Dimethylthiazol-2-yl)- } \\
\text { 2,5-diphenyltetrazolium bromide) }\end{array}$ \\
\hline $\mathrm{MNi}$ & Micronuclei \\
\hline NPBs & Nucleoplasmic bridges \\
\hline NBuds & Nuclear buds \\
\hline $\mathrm{Zn}$ & Zinc \\
\hline
\end{tabular}

Introduction

Extensive research has been undertaken to investigate the effect of zinc deficiency on DNA damage events in both in vitro and in vivo systems (Ho and Ames 2002; Ho et al. 2003; Song et al. 2009a; Song et al. 2009b; Song et al. 2009c; Yan et al. 2008). However, little is known on the effect of zinc concentration on epithelial cells within the buccal mucosa. Buccal cells can be easily obtained in a minimally invasive manner and have been used extensively 
in human in vivo studies investigating the genotoxic effects of environmental and lifestyle factors (Nersesyan and Chobanyan 2010; Nersesyan et al. 2010; Nersesyan 2006; Nersesyan and Adamyan 2004; Li et al. 1998; Munoz et al. 1987; Piyathilake et al. 1995; Prasad et al. 1995; Ramirez and Saldanha 2002; Thomas et al. 2010). Determining the nutritional requirements for optimal genome integrity in human tissue is a high priority for disease prevention as risk for developmental and degenerative diseases increases with elevated rates of genetic damage (Fenech 2010). However, the mineral micronutrient requirement for DNA damage prevention in ectodermal tissue such as buccal mucosa is virtually unexplored.

In order to better understand the effect of zinc on genome integrity in buccal cells, Human Oral Keratinocyte (HOK) primary cells were used as a model (Mitchell et al. 2010). Oral keratinocytes play a major role in cell protection by providing a major barrier to physical, microbial and chemical agents that may potentially cause local cell injury. Their involvement in proinflammatory processes involve the production of cytokines either constitutively or after a variety of stimuli (Lundqvist et al. 1994), implying that they may potentially participate in controlling oral infections through an inflammatory process involving different interleukins, such as IL-1 $\beta$ and IL-18 (Rouabhia et al. 2002). Oral keratinocytes express a variety of differentiation markers, which are influenced by calciuminduced changes in the transcription of target genes (Presland and Dale 2000). These cells share major structural and functional features as well as same gene expression patterns with the well-characterised dermal keratinocytes and provide a suitable model for cells of the buccal mucosa (Mitchell et al. 2010).

To date, there are no studies on the effect of $\mathrm{Zn}$ on genomic stability in primary HOK cells even though $\mathrm{Zn}$ is recognised as one of the key minerals that are essential in maintaining DNA integrity (Ho 2004; Dreosti 2001). The Cytokinesis Block Micronucleus Cytome (CBMN-Cyt) assay has been identified as currently the best validated biomarker of DNA damage and cytotoxicity that is sensitive to nutritional status as well as being associated with and predictive of degenerative diseases (Fenech 2010). Thus, this assay was chosen as the primary outcome measure to investigate the potential genomic stability effects of $\mathrm{Zn}$, depending on its concentration and its source compound. To provide some insight into potential molecular mechanisms, the expression of important DNA damage response proteins was measured such as $\gamma$-H2AX, Caspase 3, p53, PARP and OGG1 (Ho 2004) and metallothionein was investigated as a biomarker for $\mathrm{Zn}$ status (Hambidge 2003).

In this present study, it was hypothesised that both deficiency and excess of $\mathrm{Zn}$ could cause DNA damage and cytotoxicity, and the effect of $\mathrm{Zn}$ on these DNA damage events may be different depending on the different chemical forms. In addition, we aimed to define the optimal concentrations of $\mathrm{Zn}$ for genome stability of cultured human oral keratinocytes and to identify those biomarkers in the CBMN-Cyt assay that are most sensitive to alterations in $\mathrm{Zn}$ concentration.

In order to test these hypotheses, two $\mathrm{Zn}$ compounds were compared; Zinc Sulphate $\left(\mathrm{ZnSO}_{4}\right)$ as the most commonly used form of $\mathrm{Zn}$ in research studies and Zinc Carnosine $(\mathrm{ZnC})$ as a novel form of $\mathrm{Zn}$ that is increasingly being used as a dietary supplement possessing health-promoting effects for gastrointestinal function (Mahmood et al. 2007).

\section{Materials and methods}

HOK cell culture and study design

HOK cells are human oral keratinocytes isolated from the normal human oral mucosa and were obtained from the ScienCell Research Laboratories (Cat No 2610; ScienCell, Ca, USA) (Fig. 1). Cells were cultured in Oral Keratinocyte Medium (OKM) which is a complete medium for optimal growth of normal human oral keratinocytes in vitro. OKM consists of $500 \mathrm{ml}$ of basal medium, $5 \mathrm{ml}$ of oral keratinocyte growth supplement (OKGS, Cat. No. 2652 ScienCell Research Laboratories, Ca, USA) and $5 \mathrm{ml}$ of penicillin/ streptomycin solution (P/S, Cat. No. 0503, ScienCell Research Laboratories, Ca, USA). The medium is serumfree, HEPES and bicarbonate buffered and has a pH of 7.4. Cells were cultured in $T 75 \mathrm{~cm}^{2}$ flasks coated with poly-Llysine (Sigma, USA) solution in an incubator at $37^{\circ} \mathrm{C}$ in a $5 \% \mathrm{CO}_{2}$ humidified atmosphere. HOK cells were cultured in $500 \mu$ l volumes in 24 -well plates (Thermo Fisher Scientific, NY, USA) at an initial density of $2 \times 10^{3}$ cells $/ \mathrm{ml}$ (based on growth curve-data not shown) for 9 days and the medium was replaced every 3 days (Fig. 2b). Viable cell counts were performed via a trypan blue exclusion assay as described previously (Phillips 1973). For all experiments, cells were cultured in $\mathrm{Zn}$-depleted medium $(0 \mu \mathrm{M})$ to which $\mathrm{ZnSO}_{4}$ (Sigma Aldrich St. Louis, MO, USA) or ZnC (Hamari Chemicals Osaka, Japan) was added to obtain $\mathrm{Zn}$ concentrations of $0.4,4.0,16.0,32.0$ and $100.0 \mu \mathrm{M}$. Zn-depleted medium was prepared as follows: HOK medium was mixed with 10\% Chelex-100 (Sigma, St. Louis, MO, USA) for $2 \mathrm{~h}$ and the cycle of depletion was repeated again for another $4 \mathrm{~h}$. The chelex-treated medium was filter-sterilised prior to use in cultures.

The experiments were performed by doing 6 replicate assays or cultures per dose, and the experiments were repeated 6 times to allow an accurate estimate of intra- and inter-experimental variation. 
Fig. 1 Photomicrographs of human oral keratinocyte cells scored in the CBMN-Cyt assay $(\times 1,000)$; a mononucleated cell; b binucleated cell; c multinucleated cell; d apoptotic cell; e necrotic cell; f binucleated cell containing a micronucleus (indicated by arrow); $\mathbf{g}$ binucleated cell containing a nucleoplasmic bridge and a micronucleus (indicated by arrow); and $\mathbf{h}$ binucleated cell containing a nuclear bud (indicated by arrow)
(A)

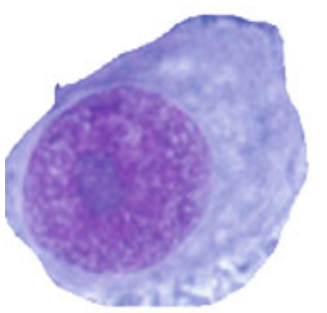

(D)

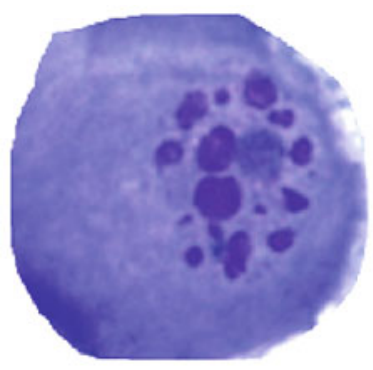

(F)

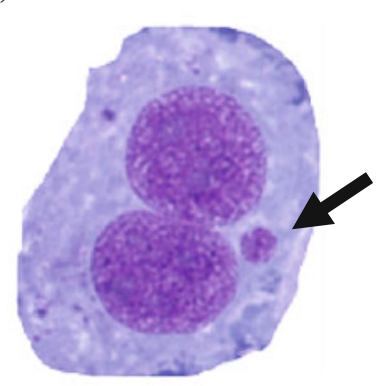

(B)

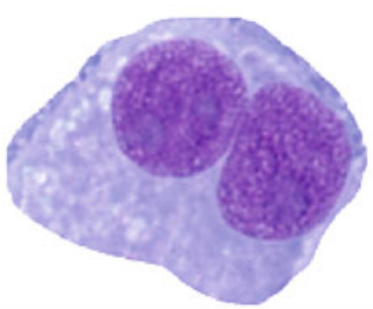

(E)

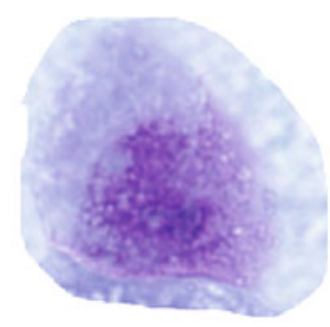

(G)

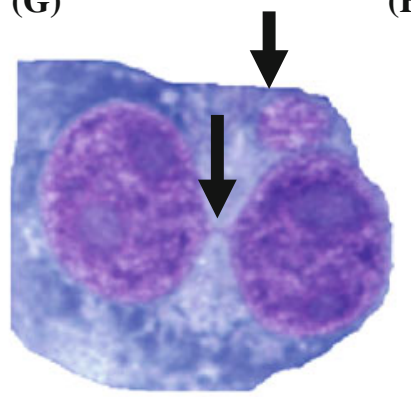

(C)

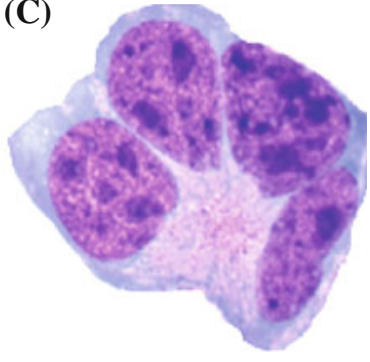

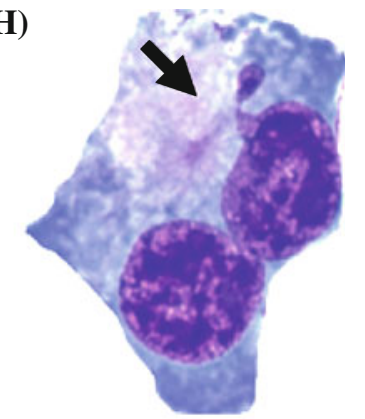

Inductively coupled plasma optical emission spectrometry (ICPOES)

ICPOES was used to determine $\mathrm{Zn}$ levels both in media and within cells after culturing for 9 days. Analysis was conducted at the Waite Analytical Services (W.A.S.School of Agriculture and Wine, University of Adelaide). Briefly, either $2 \mathrm{ml}$ of medium or cell pellets $\left(4 \times 10^{6}\right.$ cells) were incubated with $4 \%$ nitric acid and hydrogen peroxide, diluted and analysed by ICPOES as described previously (Verbanac et al. 1997). The intra- and interassay coefficient of variation (CV) for the $\mathrm{Zn}$ measurements was 9.18 and $10.59 \%$, respectively.

\section{MTT cell viability assay}

The level of viable cells was measured using the MTT assay as described previously (Mosmann 1983). Briefly, $100 \mu \mathrm{l}$ of HOK cells $\left(1 \times 10^{3}\right.$ cells $\left./ \mathrm{ml}\right)$ were cultured at different $\mathrm{Zn}$ concentrations for 9 days in 96-well plates (Thermo Fisher Scientific, NY, USA) coated with polyL-Lysine (Sigma, St. Louis, MO, USA). Medium was changed on day 3 and day 6 . Ten microlitres of MTT salt solution $(5 \mathrm{mg} / \mathrm{ml}$-Sigma, St. Louis, MO, USA) was added on day 9 to each well and incubated for $4 \mathrm{~h}$. Solubilising solution $[10 \%$ Sodium Dodecyl Sulphate, SDS (Sigma, St. Louis, MO, USA)] in $0.01 \mathrm{M} \mathrm{HCl}$ (BDH, Analar, England) was added to the plate and further incubated overnight at $37^{\circ} \mathrm{C}$. Absorbance was read with an ELISA microplate reader (SpectraMax 250, Molecular Devices, CA, USA) and the difference in optical density at 650 and $570 \mathrm{~nm}$ measured. The intra- and inter-assay coefficient of variation (CV) for the MTT assay was 18.16 and $25.29 \%$, respectively.

\section{Comet assay}

The comet assay was used in this study to measure DNA strand breaks and alkaline-labile sites in cells cultured for 9 days. The assay was conducted under alkaline conditions as described previously (Singh et al. 1988; Tice et al. 2000) with slight modification for use with a high throughput CometSlide HT (Trevigen Inc. Cat 4252-02 K-01). Hundred cells were randomly selected from each spot and 
Fig. 2 a Photomicrograph of human oral keratinocyte cell line $(\times 40)$. b Schematic diagram for 9-day tissue culture protocol for HOK cells testing for cytotoxic and genotoxic effects of $\mathrm{Zn}$. HOK human oral keratinocytes, MTT [3-(4,5Dimethylthiazol-2-yl)-2,5diphenyltetrazolium bromide]; ICPOES inductively coupled plasma optical emission spectrometry, CBMN-Cyt cytokinesis block micronucleus cytome assay, Cyto$B$ cytochalasin $\mathrm{B}$. The initial concentration of cells was $2 \times 10^{3}$ cells $/ \mathrm{ml}$ on day 0 and cells were cultured in $500 \mu \mathrm{l}$ volumes

(A)

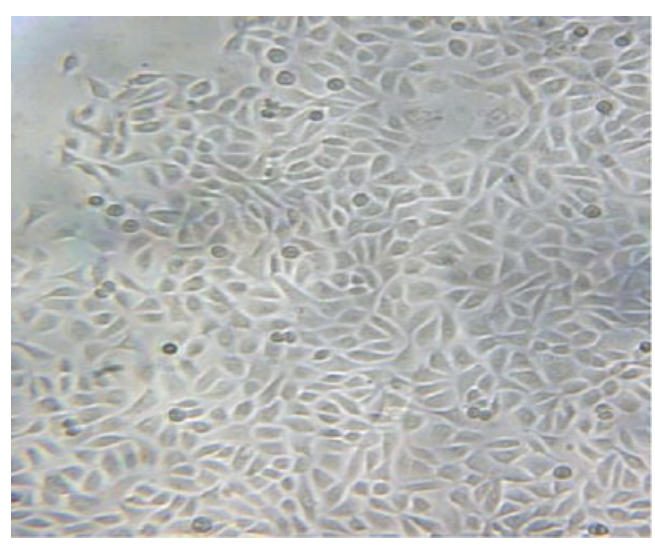

(B)

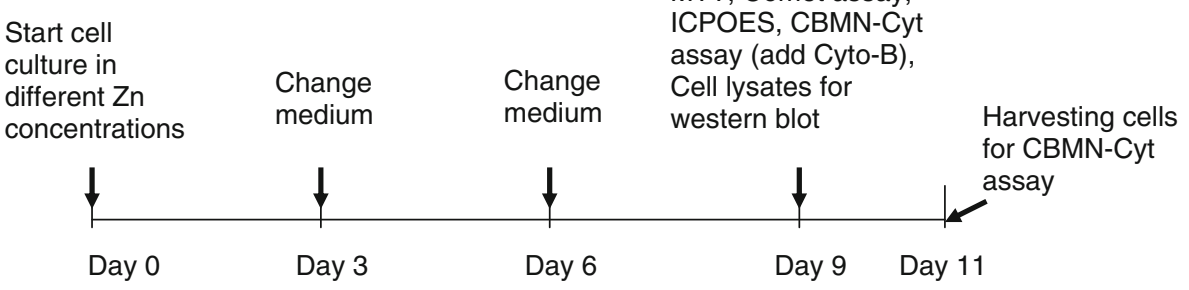

scored with online software (Tritek-http://autocomet. com/main_home.php) for tail moment and tail intensity. Tail moment (tail length $\times$ DNA density) and tail intensity (\% DNA in tail) were used as indicators of DNA damage. The intra- and inter-assay CV for the tail moment measured was 21.49 and $32.22 \%$, and for tail intensity was 12.63 and $17.94 \%$, respectively.

\section{CBMN-Cyt assay}

In the CBMN-Cyt assay, DNA damage biomarkers are scored in cytokinesis-blocked binucleated cells. The DNA damage biomarkers scored are micronuclei ( $\mathrm{MNi}$, a biomarker for whole chromosome loss or chromosome breakage), nucleoplasmic bridges (NPBs, a biomarker of DNA misrepair and/or telomere to telomere end fusions) and nuclear buds (NBuds, a biomarker of gene amplification) (Fenech 2007). Cytochalasin B (Sigma, St. Louis, MO, USA-4.5 $\mu \mathrm{g} / \mathrm{ml}$ ) was added and cells further incubated for another $48 \mathrm{~h}\left(37^{\circ} \mathrm{C}, 5 \% \mathrm{CO}_{2}\right)$. Cells were then harvested onto microscope slides on day 11 using a cytocentrifuge as per the manufacturer's instructions (Shandon Products, UK). Slides were air-dried for $10 \mathrm{~min}$, fixed in Diff-Quik fixative for 10 min and stained using Diff-Quik stains (Lab Aids, Australia).

A total of 3,600 cells were scored per dose (treatment) $(100 \times 6$ slides $\times 6$ experiments $)$ and classified to determine the ratios of mononucleate, binucleate $(\mathrm{BN})$, multinucleate, apoptotic and necrotic cells. These ratios were used to determine the nuclear division index (NDI) which is a biomarker of cytostasis where cytostatic effects are readily estimated from the ratio of mono-, bi- and multinucleated cells. The NDI provides a measure of the proliferative status of the viable cell fraction. It is therefore an indicator of cytostatic effects, and in the case of lymphocytes, it is also a measure of mitogenic response, which is useful as a biomarker of immune function (Fenech 2007). NDI is calculated according to the method of Eastmond and Tucker (Eastmond and Tucker 1989). Five hundred viable cells are scored to determine the frequency of cells with 1 , 2, 3 or 4 nuclei and calculate the NDI using the formula $\mathrm{NDI}=(\mathrm{M} 1+2 \mathrm{M} 2+3 \mathrm{M} 3+4 \mathrm{M} 4) / \mathrm{N}$, where $\mathrm{M} 1-\mathrm{M} 4$ represent the number of cells with 1-4 nuclei and $\mathrm{N}$ is the total number of viable cells scored (excluding necrotic and apoptotic cells). The NDI is a useful parameter for comparing the mitogenic response of lymphocytes and cytostatic effects of agents examined in the assay.

Cytotoxicity events were assessed by the frequency of necrotic and apoptotic cells. A total of $18000 \mathrm{BN}$ cells per dose (treatment) $(500 \times 6$ slides $\times 6$ experiments $)$ were scored for genome damage indices ( $\mathrm{MNi}, \mathrm{NPBs}$ and NBuds). The scoring criteria for these cells are based on those originally described by (Fenech 2007). Photomicrographs of the different cell types and nuclear anomalies scored in the CBMN-Cyt assay are shown in Fig. 1. The intra-assay and inter-assay CV for CBMN-Cyt assay biomarkers was as follows: Apoptotic cells $(23.82,48.73 \%)$; Necrotic cells $(31.63,45.56 \%)$; NDI $(2.19,5.23 \%)$; $\mathrm{MNi}$ 
(73.21, 102.58\%); NPB (62.61, 86.37\%); NBuds (57.13, $91.58 \%)$, respectively.

\section{Western blotting}

Equal amount of protein lysate $(20 \mathrm{mg} / \mathrm{lane})$ was separated using SDS-PAGE on a $4-12 \%$ bis-Tris gel (Invitrogen, CA, USA) and transferred to nitrocellulose membrane (Amersham Hybond ${ }^{\mathrm{TM}}$ ECL $^{\mathrm{TM}}$, GE Healthcare, UK). The membranes were probed with antibodies to specific proteins as follows: mouse anti-poly-ADP-ribose polymerase (PARP; BD Pharmingen, CA, USA), rabbit anti-8-oxoguanine glycosylase (OGG1; Novus Biologicals, USA), mouse anti-p53 (Calbiochem, USA), mouse anti-metallothionein (MT; Dako, Denmark), mouse anti $\gamma$-H2AX (Millipore, USA) and mouse anti $\beta$-actin (Sigma, St. Louis, MO, USA). Bound antibodies were detected using either goat anti-mouse IgG horseradish peroxidase or goat antirabbit IgG horseradish peroxidase (Dako, Denmark) and developed with Amersham ${ }^{\mathrm{TM}}$ ECL $^{\mathrm{TM}}$ western blotting detection reagent (GE Healthcare, UK). Bands of interest were acquired using luminescent image analyser LAS-4000 (FujiFilm, Tokyo, Japan), and quantification of bands on Western blot membrane was performed using the Multi Gauge version 3.0 program (FujiFilm, Tokyo, Japan). The data are presented as a ratio of protein expression relative to $\beta$-actin. The intra-assay and inter-assay $\mathrm{CV}$ for protein expression was as follows: Caspase 3 (10.86, 17.76\%); Metallothionein $(13.34,18.60 \%)$; PARP (14.14, 16.69\%); OGG1 (27.39, 35.74\%); p53 (7.36, 10.19\%); $\gamma$-H2AX $(17.68,26.11 \%)$, respectively.

\section{Statistical analysis}

For each treatment, six replicate measurements were performed within each of six separate experiments performed on separate days $(n=6)$. All end points measured were tested for Gaussian distribution by using the KolmogorovSmirnov test. One-way analysis of variance (ANOVA) followed by Tukey's post hoc tests for data with Gaussian distribution was performed to compare the effects of different $\mathrm{Zn}$ concentrations. The non-parametric Friedman test followed by Dunn's multiple comparison test was used for data that did not exhibit Gaussian distribution. Twoway ANOVA was used in this study to measure the difference in effects between $\mathrm{ZnSO}_{4}$ and $\mathrm{ZnC}$ and the \% variance for biomarker results that could be explained by $\mathrm{Zn}$ concentration and $\mathrm{Zn}$ compound used. Data are expressed as mean \pm standard error with $P<0.05$ considered statistically significant. Statistical analyses were performed using Prism 5.0 (GraphPad Inc., San Diego, CA).

\section{Results}

Cellular zinc concentrations

Zn-depleted cells showed a significant reduction in cellular $\mathrm{Zn}$ levels $(P<0.0001)$ and there was no effect on other divalent metals (Copper and Iron) (Table 1). Cells supplemented with either $\mathrm{ZnSO}_{4}$ or $\mathrm{ZnC}$ showed a significant dose-related increase in cellular $\mathrm{Zn}(P<0.0001)$ with increased concentration of $\mathrm{Zn}$ in medium (Fig. 3a). The increment, however, appeared to be slightly greater for $\mathrm{ZnSO}_{4}$ relative to $\mathrm{ZnC}$ based on the observed trends and the associated \% variance estimates (effect of type of $\mathrm{Zn}$ compound: $1.47 \%, P=0.0004$, effect of concentration: $92.92 \%, P<0.0001)$.

Effect of Zn concentrations on cell viability measured via MTT assay

A significant decrease in viable cells in $\mathrm{Zn}$-depleted cultures and with excess $\mathrm{Zn}(P<0.0001)$ is shown in Fig. 3 b. Cell viability appeared to be optimal between the range 4-6 $\mu \mathrm{M}$ for both $\mathrm{ZnC}$ and $\mathrm{ZnSO}_{4}$. At $32 \mu \mathrm{M}$, both $\mathrm{Zn}$ compounds showed a significant decrease in viable cell number, and at $100 \mu \mathrm{M}$, both $\mathrm{Zn}$ compounds exhibited severe cytotoxic effects $(P<0.0001)$. Two-way ANOVA analysis showed better viability for cells treated with $\mathrm{ZnSO}_{4}$ compared with $\mathrm{ZnC}$, at 4,16 and $32 \mu \mathrm{M}$ $(P<0.05)$, but the greatest $\%$ variance was attributable to $\mathrm{Zn}$ concentration (effect of type of $\mathrm{Zn}$ compound: $9.59 \%$, $P<0.0001$, effect of concentration: $68.63 \%, P<0.0001)$.

Effect of Zn concentrations on DNA strand breaks measured via comet assay

Comet assay was used to determine DNA strand breaks and alkali-labile sites. DNA damage is often associated with cell death; therefore, it is critical that the highest dose tested should not induce excessive cytotoxicity. Hence, treatment with $\mathrm{ZnSO}_{4}$ and $\mathrm{ZnC}$ at $100 \mu \mathrm{M}$ was excluded as cell viability was less than $5 \%$. Two endpoints were measured in this assay: tail moment (TM) and tail intensity (TI). TI represents percentage of DNA in the tail and TM represents a measure of tail length multiplied by the measure of DNA in the tail as a metric for DNA migration (Olive et al. 1990). Figure 4a-d shows a significant increase in both TM and TI for Zn-depleted cells $(P<0.05)$. A reduction in both TM and TI was observed with increasing zinc concentrations. However, at $32 \mu \mathrm{M}$, values for TM and TI started to increase, suggesting a U-shaped dose-response curve. There were no significant differences in values for both TM and TI for cells treated 
with $\mathrm{ZnSO}_{4}$ or $\mathrm{ZnC}$ (Tail moment-effect of type of $\mathrm{Zn}$ compound: $0.45 \%, P=0.3950$, effect of concentration: $66.70 \%, P<0.0001$; Tail Intensity-effect of type of $\mathrm{Zn}$ compound: $0.01 \%, P=0.9121$, effect of concentration: $55.87 \%, P<0.0001)$.

Effect of Zn concentration on baseline levels of cytotoxicity and chromosome damage measured by the CBMN-Cyt assay

Zn-depleted cells showed the highest percentages of necrotic and apoptotic cells $(P<0.05)$ (Fig. 5a-d). Increasing concentrations of $\mathrm{Zn}$ showed a reduction in the percentage of both necrotic and apoptotic cells $(P<0.05)$. Figure $5 \mathrm{e}-\mathrm{f}$ shows a reduction in NDI for $\mathrm{Zn}$-depleted cells $(P<0.05)$, while NDI increased with increasing $\mathrm{Zn}$ concentration indicating a cystostatic effect of $\mathrm{Zn}$ deficiency. There was no difference in apoptosis, necrosis and cytostasis (NDI) between $\mathrm{ZnSO}_{4}$ and $\mathrm{ZnC}$ at any of the concentrations tested (Apoptosis-effect of type of $\mathrm{Zn}$ compound: $0.00 \%, P=0.9798$, effect of concentration: $55.73 \%, P<0.0001$; Necrosis-effect of type of $\mathrm{Zn}$ compound: $0.06 \%, P=0.8107$, effect of concentration: $49.13 \%, P<0.0001$; NDI-effect of type of $\mathrm{Zn}$ compound: $5.27 \%, P=0.0432$, effect of concentration: $31.83 \%, P<0.05)$.

In order to measure chromosome damage, $\mathrm{MNi}$, NPBs and NBuds were scored in binucleated cells as shown in Fig. 1. Figure $6 \mathrm{a}-\mathrm{f}$ shows a significant increase in frequency of MNi and NPBs for Zn-depleted cells $(P<0.05)$. A non-significant increase in NBuds frequency was observed in Zn-depleted cells. Zn-supplemented cells showed a dose-related reduction in DNA damage events compared with $\mathrm{Zn}$-depleted cells $(P<0.05)$. Lowest DNA damage was observed at $4 \mu \mathrm{M}$ and $16 \mu \mathrm{M}$ and this trend is similar for both $\mathrm{ZnSO}_{4}$ and $\mathrm{ZnC}$. There were no significant differences in the frequencies of $\mathrm{MNi}$, NPBs, NBuds for cells treated with $\mathrm{ZnSO}_{4}$ and $\mathrm{ZnC}$ (MNi-effect of type of Zn compound: $0.66 \%, P=0.4884$; effect of concentration: $30.41 \%, P<0.05$; NPBs-effect of type of $\mathrm{Zn}$ compound: $0.08 \%, P=0.8155$, effect of concentration:.26.90\%, $P<0.05$; NBuds-effect of type of $\mathrm{Zn}$ compound: $0.14 \%, P=0.7556$, effect of concentration: $26.03 \%, P<0.05)$.

Western blot analysis

Western blot was used to measure expression of key proteins involved in the molecular mechanisms by which cells respond to $\mathrm{Zn}$ status or genotoxic and cytotoxic events induced by $\mathrm{Zn}$ depletion or excess. Higher levels of PARP, OGG1 and p53 were observed in Zn-depleted cells $(P=0.065,<0.0001,<0.05$, respectively) (Fig. 7a-c); 

intracellular zinc in $\mathrm{HOK}$ cells treated with $a \mathrm{ZnSO}_{4}$ and $b \mathrm{ZnC}$, at increasing depleted medium. Groups not sharing the same letter are significantly different to each other ( $P$ values refer to Oneway ANOVA analysis: $P<0.05)$. Results shown are mean \pm standard error $(n=6)$. $N M$ not measurable. b Level of viable cells in cultures treated with $a \mathrm{ZnSO}_{4}$ and $b \mathrm{ZnC}$ at increasing $\mathrm{Zn}$ concentration measured via MTT assay. Groups not sharing the same letter are significantly different One-way ANOVA analysis: $P<0.05)$. Results shown are mean \pm standard error $(n=6)$
Fig. 3 a Concentration of concentrations of $\mathrm{Zn}$. $0 \mu \mathrm{M}$ represents cells grown in $\mathrm{Zn}$ to each other $(P$ values refer to
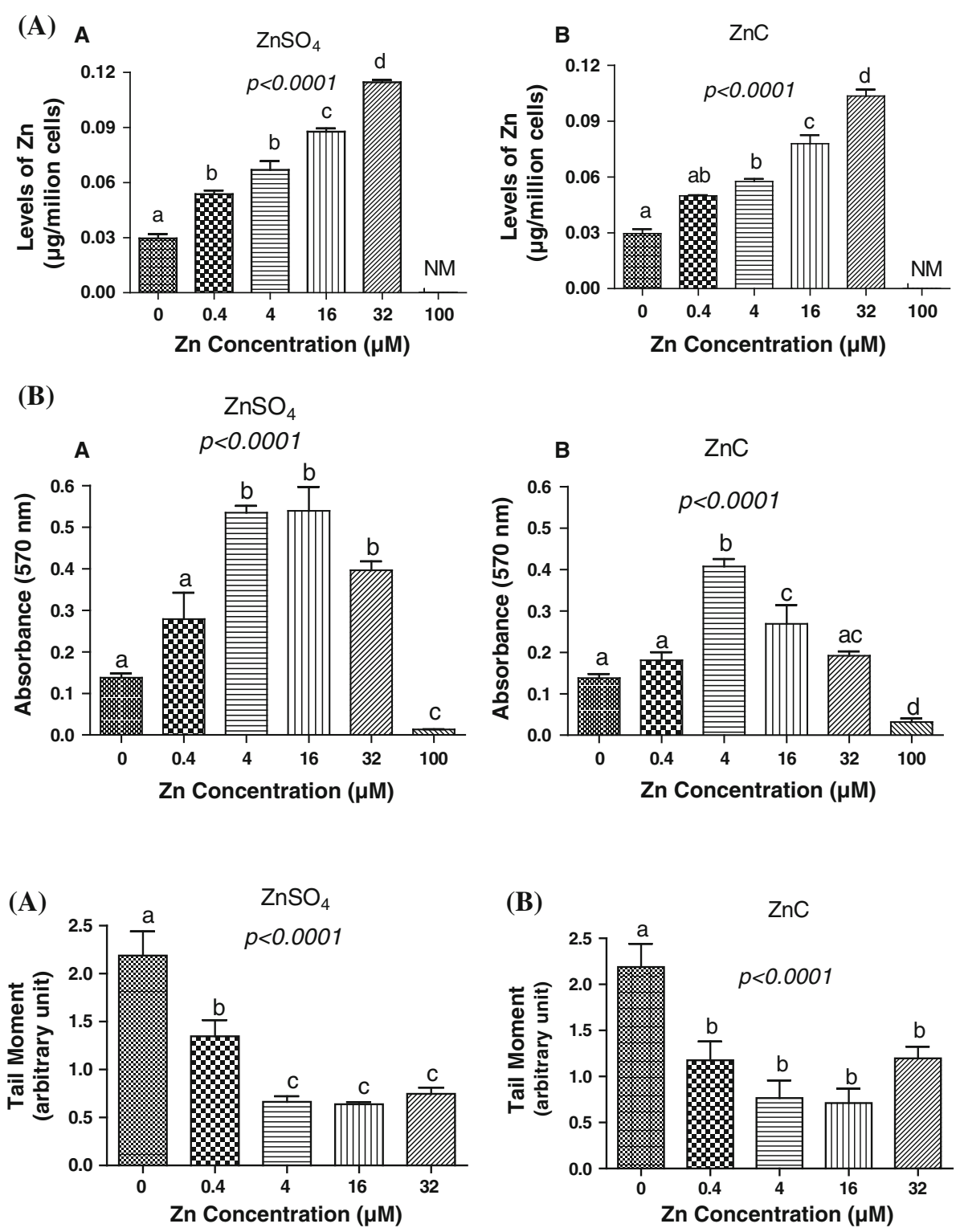

Fig. 4 Tail moment values for cells treated with a $\mathrm{ZnSO}_{4}$ and b $\mathrm{ZnC}$; Tail intensity values for cells treated with $\mathbf{c} \mathrm{ZnSO}_{4}$ and d $\mathrm{ZnC}$ at increasing concentrations of $\mathrm{Zn}$. Groups not sharing the same superscript letter are significantly different to each other ( $P$ values refer to One-way ANOVA analysis: $P<0.05)$. Results are shown as mean \pm standard error $(n=6)$

(C)

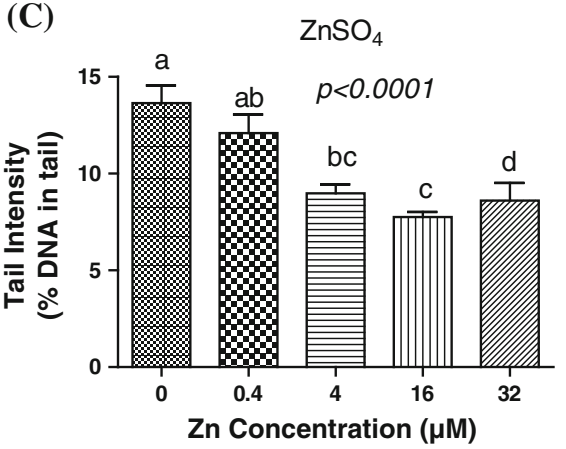

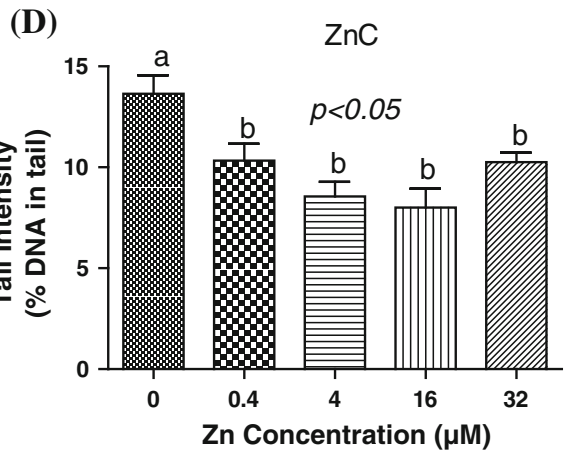

however, Zn-supplemented cells did not show any significantly different levels of these proteins at $\mathrm{Zn}$ concentrations ranging from 0.4 to $32 \mu \mathrm{M}$. Increased levels of $\gamma$-H2AX levels were observed in $\mathrm{Zn}$-depleted cells suggesting increased DNA breaks, and $\gamma-\mathrm{H} 2 \mathrm{AX}$ expression was minimised at $4 \mu \mathrm{M} \mathrm{Zn}$ in $\mathrm{ZnSO}_{4}$ cultures $(P<0.05)$ (Fig. 7d). Zn-depleted cells also showed higher expression of Caspase 3 as compared to the other groups $(P<0.05)$ 
Fig. 5 Cytotoxicity and cytostatic end points with increasing $\mathrm{Zn}$ concentration scored using CBMN-Cyt assay in HOK cells on day 11: a percentage of apoptotic cells from cultures treated with $\mathrm{ZnSO}_{4}$, b percentage of apoptotic cells from cultures treated with $\mathrm{ZnC}$, c percentage of necrotic cells from cultures treated with $\mathrm{ZnSO}_{4}$, d percentage of necrotic cells from cultures treated with $\mathrm{ZnC}$, e NDI of cultures treated with $\mathrm{ZnSO}_{4}$, and $\mathbf{f} \mathrm{NDI}$ of cultures treated with $\mathrm{ZnC}$. Groups not sharing the same letter are significantly different to each other. Results are shown are mean \pm standard error $(n=6)$. $(P$ values refer to One-way ANOVA analysis: $P<0.05$ )
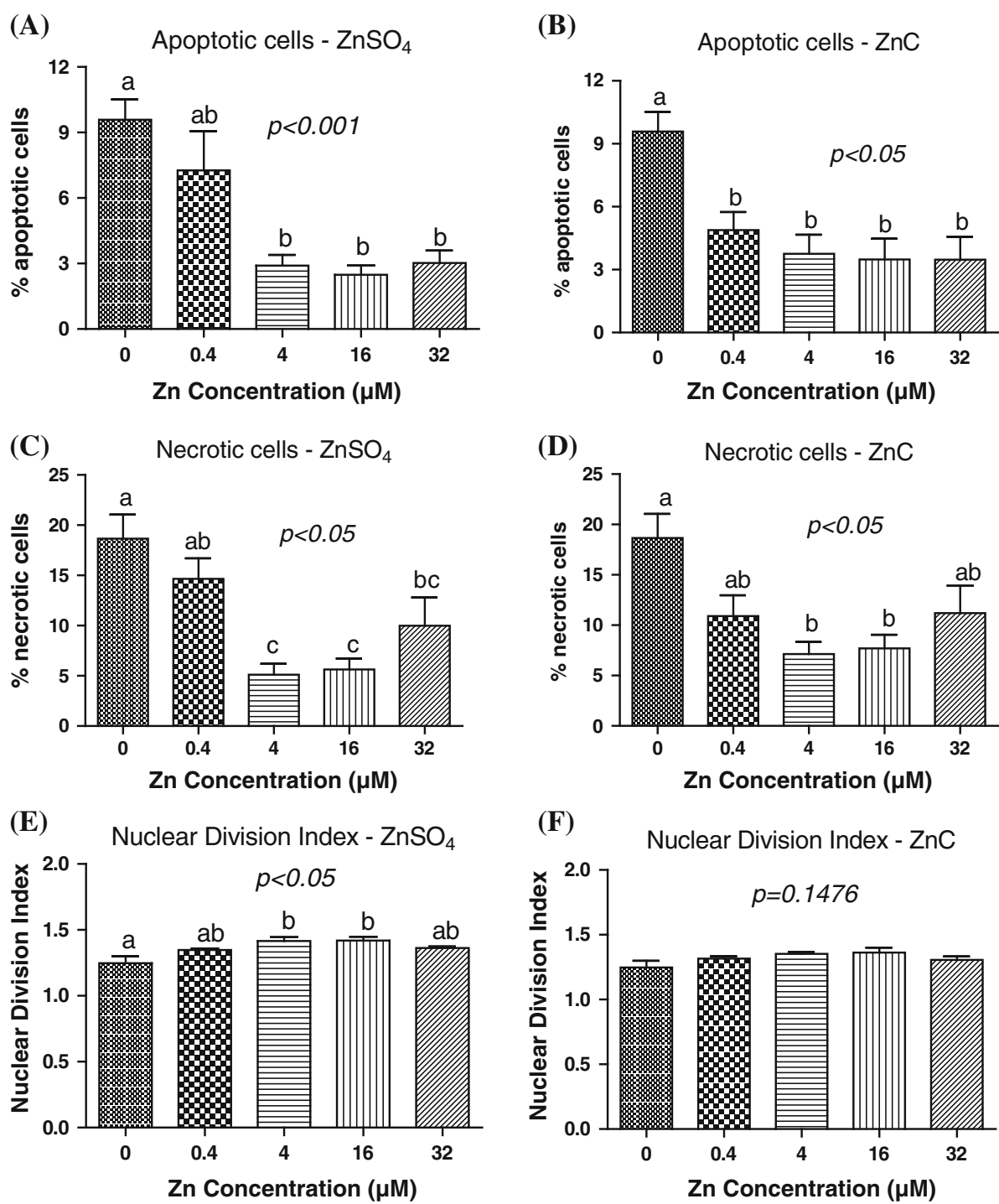

(F)

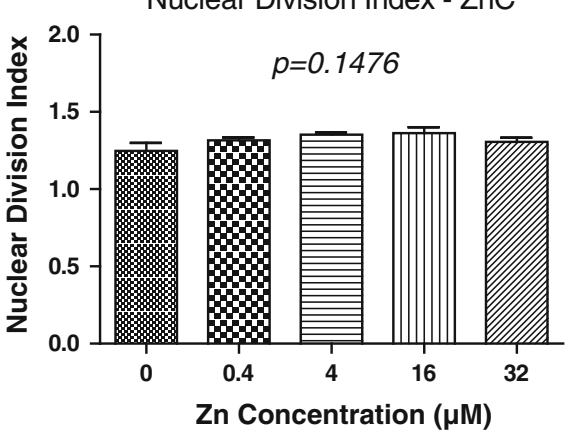

(Fig. 7e) indicative of apoptosis activity induced via Caspase 3. Levels of metallothionein (MT) increased in a dosedependent manner and were significantly higher in cells grown at 16 and $32 \mu \mathrm{M}$ compared with all other groups confirming the relevance of this biomarker as an indicator of $\mathrm{Zn}$ status (Fig. 7f). There was no difference in any of the protein expression biomarkers between $\mathrm{ZnSO}_{4}$ and $\mathrm{ZnC}$ at any of the concentrations tested (PARP: effect of type of Zn compound: $1.56 \%, P=0.1794$, effect of concentration: $49.12 \%, P<0.0001$; OGG1: effect of type of $\mathrm{Zn}$ compound: $1.92 \%, P=0.0291$, effect of concentration: $70.55 \%, P<0.0001$; p53: effect of type of $\mathrm{Zn}$ compound: $0.55 \%, P=0.0004$, effect of concentration: $95.67 \%$, $P<0.0001 ; \gamma-\mathrm{H} 2 \mathrm{AX}$-effect of type of $\mathrm{Zn}$ compound: $0.15 \%, P=0.6699$, effect of concentration: $59.43 \%$, $P<0.0001$; Caspase 3: effect of type of $\mathrm{Zn}$ compound: $0.10 \%, P=0.5738$, effect of concentration: $81.59 \%$, $P<0.0001 ;$ MT - effect of type of Zn compound: $0.21 \%$, $P=0.2059$, effect of concentration: $91.79 \%, P<0.0001$ ).
Cytotoxicity and genotoxicity effect of HOK cells in optimal medium

Data on HOK cells grown in optimal medium [Oral Keratinocyte Medium (OKM) which is a complete medium for optimal growth of normal human oral keratinocytes in vitro] are presented in Table 2. OKM consists of $500 \mathrm{ml}$ of basal medium, $5 \mathrm{ml}$ of oral keratinocyte growth supplement (OKGS, Cat. No. 2652 ScienCell Research Laboratories, Ca, USA) and $5 \mathrm{ml}$ of penicillin/streptomycin solution (P/S, Cat. No. 0503, ScienCell Research Laboratories, Ca, USA). The optimal culture medium used which consists of basal medium with additional oral keratinocytes growth supplement and penicillin/streptomycin solution contains $4 \mu \mathrm{M}$ of $\mathrm{Zn}$. Cells grown in optimal medium did not show any cytotoxicity and genotoxicity effects as compared to $\mathrm{Zn}$-depleted cells. The relationship between DNA damage and cells grown in optimal medium was very similar to cells grown in additional $4 \mu \mathrm{M}$ of $\mathrm{Zn}$. 
Fig. 6 DNA damage biomarker end points scored using CBMNCyt assay in HOK cells on day 11 in relation to increasing $\mathrm{Zn}$ concentration: a frequency of $\mathrm{MNi}$ in $1000 \mathrm{BN}$ cells from cultures treated with $\mathrm{ZnSO}_{4}$, b frequency of $\mathrm{MNi}$ in $1000 \mathrm{BN}$ cells from cultures treated with $\mathrm{ZnC}$, $\mathbf{c}$ frequency of NPBs in $1000 \mathrm{BN}$ cells from cultures treated with $\mathrm{ZnSO}_{4}$, d frequency of NPBs in $1000 \mathrm{BN}$ cells from cultures treated with $\mathrm{ZnC}$, e frequency of NBuds in 1000 $\mathrm{BN}$ cells from cultures treated with $\mathrm{ZnSO}_{4}$, and $\mathbf{f}$ frequency of NBuds in $1000 \mathrm{BN}$ cells from cultures treated with $\mathrm{ZnC}$. Groups not sharing the same letter are significantly different to each other. ( $P$ values refer to One-way ANOVA analysis: $P<0.05)$. Results shown are mean \pm standard error $(n=6)$
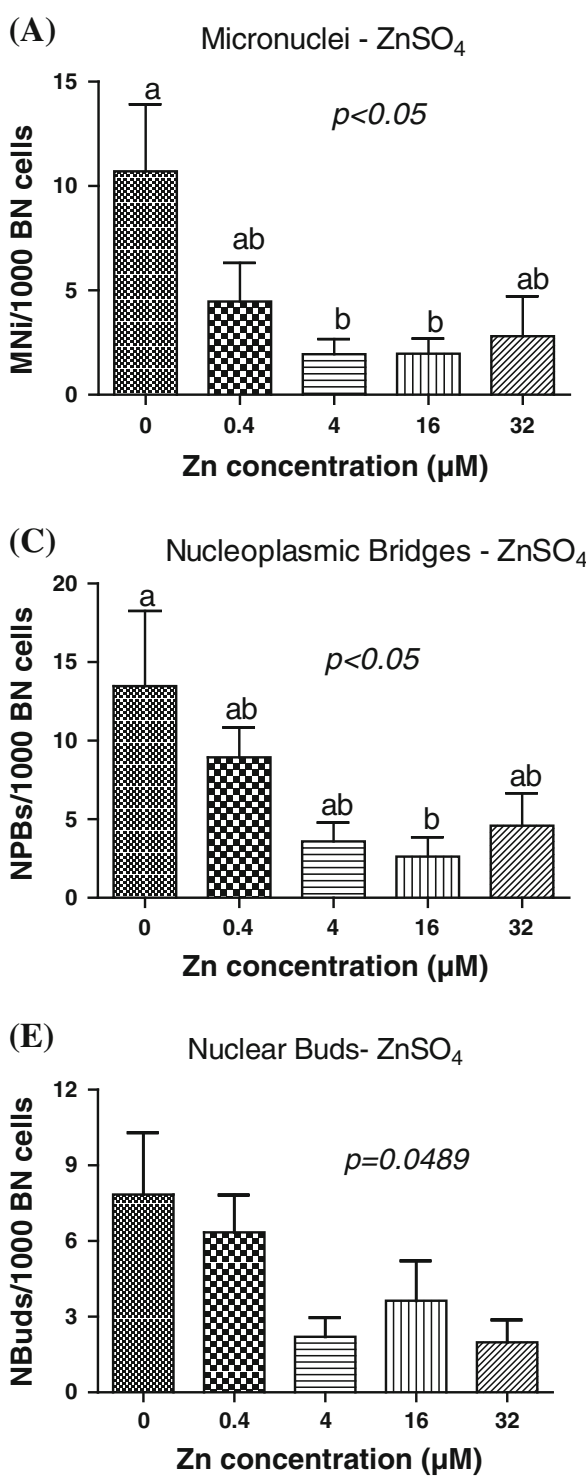
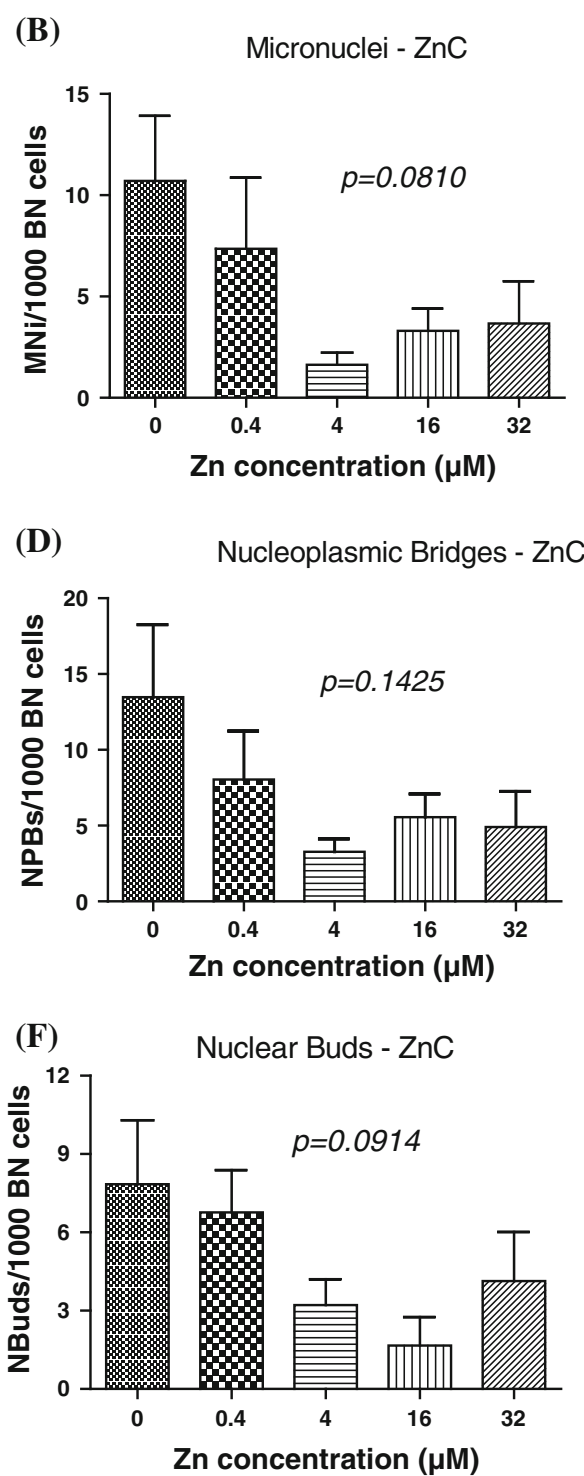

\section{Discussion}

The results of this study show that both $\mathrm{Zn}$ deficiency and Zn excess increase cytotoxicity and DNA damage events in HOK cells and that $\mathrm{Zn}$ deficiency induces the expression of DNA damage response and/or repair proteins. This study highlights the critical role of $\mathrm{Zn}$ in genome maintenance and identifies the optimal concentration of $\mathrm{Zn}$ required for maintaining genomic stability in human oral keratinocytes.

Bioavailability of $\mathrm{Zn}$ is controlled by $\mathrm{Zn}$ homoeostatic mechanisms that involve $\mathrm{Zn}$ uptake, efflux and $\mathrm{Zn}$ distribution in cells (Murgia et al. 2006). When comparing dose-response effects of zinc concentrations in medium and intracellular zinc (Fig. 3) and metallothionein expression (Fig. 7), it is evident that intracellular zinc measurements are more reliable and more specific biomarker of $\mathrm{Zn}$ status. In this present study, cellular $\mathrm{Zn}$ in cells treated with $\mathrm{ZnSO}_{4}$ was slightly higher compared with cells treated with
$\mathrm{ZnC}$. This may be due to the chelating property of carnosine in $\mathrm{ZnC}$ that may result in reduced bioavailability compared with $\mathrm{ZnSO}_{4}$ (Sharif et al. 2011). Carnosine from $\mathrm{ZnC}$ may have contributed to the protective effects of this compound and could explain why $\mathrm{ZnC}$ was as efficacious in preventing DNA damage and cytotoxicity as $\mathrm{ZnSO}_{4}$ despite a lower intracellular $\mathrm{Zn}$ concentration. Carnosine is an antioxidant, derived from the amino acids $\beta$-histidine and L-alanine, and has been shown to protect against X-ray irradiation and promote wound healing (Klebanov et al. 1998; Hipkiss 1998; Hipkiss and Chana 1998; Hipkiss et al. 1997; Hipkiss et al. 1998). Several potential antioxidant mechanisms which maybe involved include: (a) its chelating action against metal ions; (b) superoxide-dismutase (SOD)-like activity; and (c) ROS and free radical scavenging (Babizhayev et al. 1994; Chan and Decker 1994; Chan et al. 1994). Similarly, it is possible that some observed effects of $\mathrm{ZnSO}_{4}$ may have been influenced not 
(A)

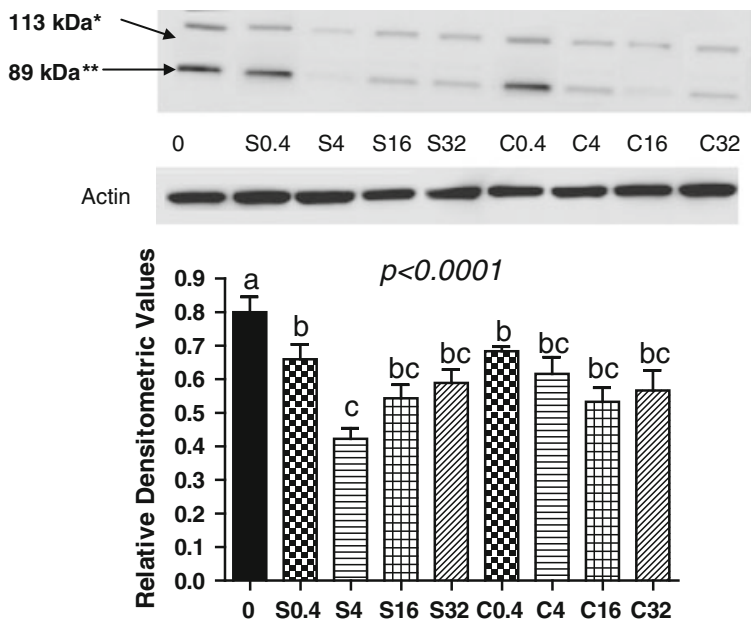

(B)
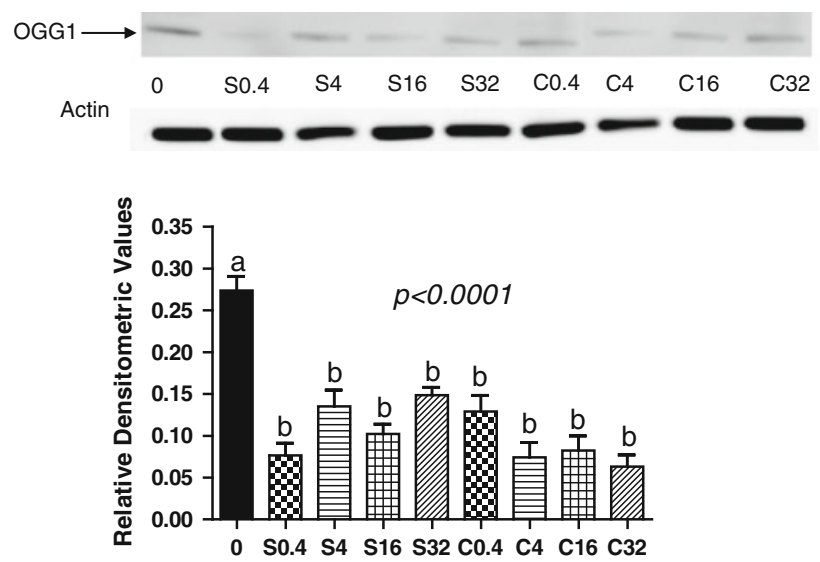

(C)
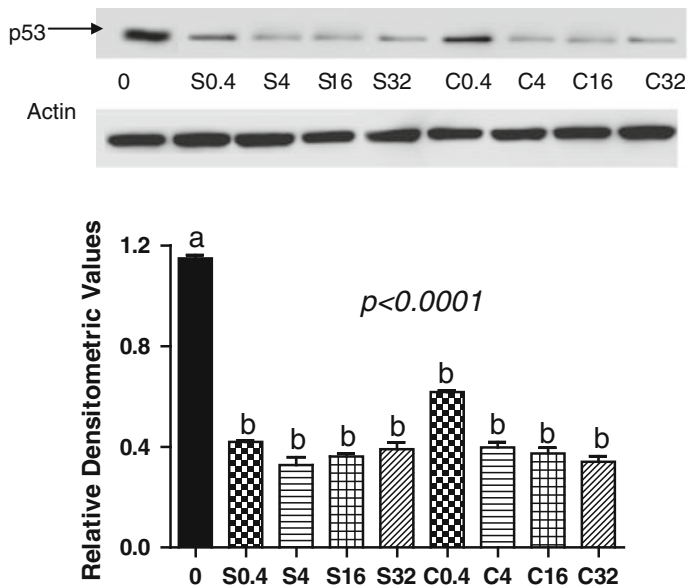

Fig. 7 The effects of zinc concentration in HOK cells on levels of a Poly (ADP-ribose) polymerase (PARP); b 8-oxoguanine glycosylase (OGG1); c p53; d $\gamma$-H2AX; (e) Caspase 3; f Metallothionein (MT) expressed in HOK cells following 9 days of culture, as determined by western blot analysis. $S$ zinc sulphate, $C$ zinc carnosine, 0: Zinc depleted cells, 0.4: $0.4 \mu \mathrm{M} \mathrm{ZnS}$ and C, 4: $4 \mu \mathrm{M}$ $\mathrm{ZnS}$ and $\mathrm{C}, 16: 16 \mu \mathrm{M} \mathrm{ZnS}$ and $\mathrm{C}, 32: 32 \mu \mathrm{M} \mathrm{ZnS}$ and $\mathrm{C}$, *intact
(D)

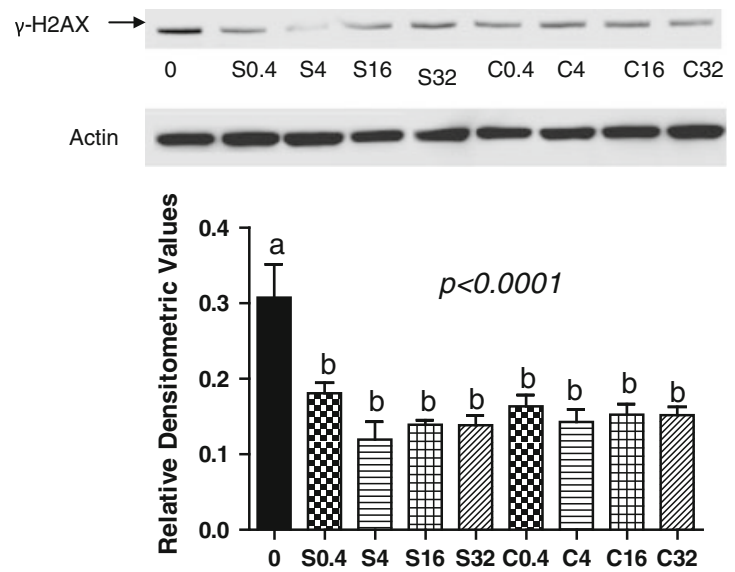

(E)

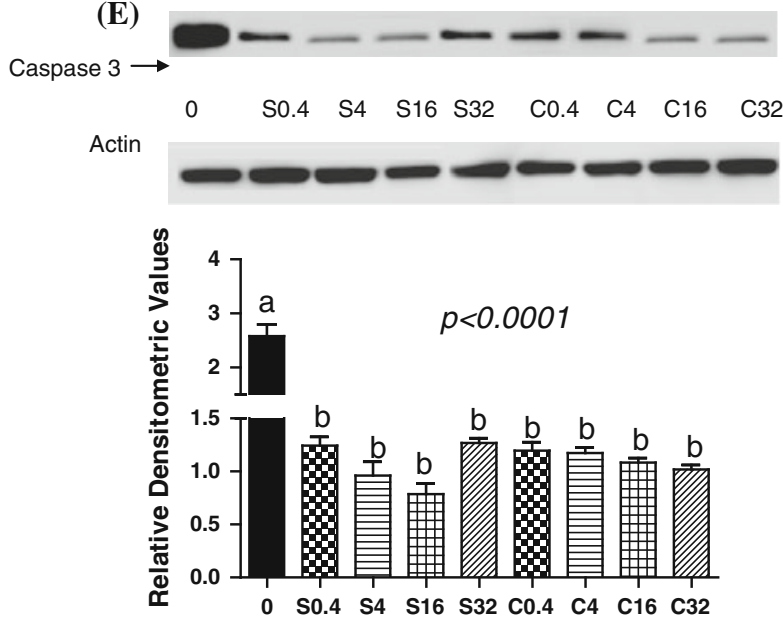

(F)
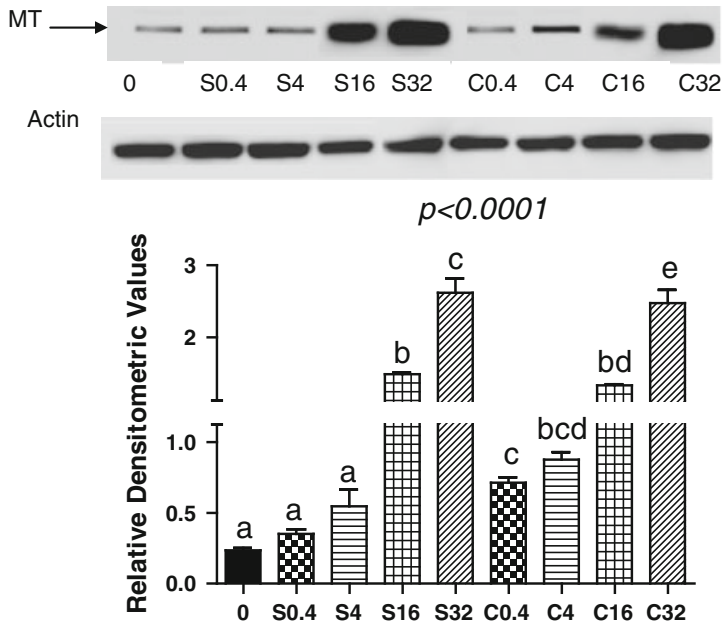

PARP segments; **cleaved PARP segments. Representative western blot are shown in the inserts. Relative densitometric values are values for each sample divided by $\beta$-actin. Groups not sharing the same letter are significantly different to each other. ( $P$ values refer to One-way ANOVA analysis: $P<0.05)$. Results shown are mean \pm standard error $(\mathrm{n}=6)$ 
only by $\mathrm{Zn}$ but also by the $\mathrm{SO}_{4}{ }^{2-}$ ion. However, evidence for this possibility is lacking in the literature. The observation that metallothionein expression was not different between $\mathrm{ZnC}$ and $\mathrm{ZnSO}_{4}$ suggests that differences in $\mathrm{Zn}$ status are unlikely to explain any differences in genotoxicity and cytotoxicity that may be observed with these two $\mathrm{Zn}$ compounds. High zinc concentrations may also compete for uptake of other divalent cationic metals causing toxic effects not directly dependent on zinc. However, no significant difference was found in the levels of copper and iron in the different zinc concentrations.

Supplementation with $\mathrm{Zn}$ at 4 and $16 \mu \mathrm{M}$ proved to be most beneficial in reducing genomic instability in vitro. Similar findings were found in a previous study conducted using the WIL2-NS lymphoblastoid cell line using the same protocol and approach (Sharif et al. 2011). Both deficient (Zn-depleted medium, $0 \mu \mathrm{M}$ ) and the higher concentrations of $\mathrm{Zn}(32$ and $100 \mu \mathrm{M}$ ) were found, in both this study on HOK cells and the one on WIL2-NS cells, to induce elevated levels of cell death and DNA strand breaks suggesting a U-shaped dose response in epithelial and lymphoblastoid cells. The physiological range for $\mathrm{Zn}$ is reported to be between 2 and $15 \mu \mathrm{M}$ (Chang et al. 2006). Our data showed that physiological concentrations of $\mathrm{Zn}$ had beneficial effect on the genomic stability of HOK cells, whereas at lower concentration of $\mathrm{Zn}$ and maximal pharmacologic concentration of $100 \mu \mathrm{M}$, Zn appeared to cause severe cellular toxicity. However, this finding is in contrast to that reported by Sliwinski et al. (Sliwinski et al. 2009) who showed that $\mathrm{ZnSO}_{4}$ at $100 \mu \mathrm{M}$ did not affect the viability of primary human lymphocytes suggesting that sensitivity to $\mathrm{Zn}$ toxicity may be dependent on cell type or cell culture conditions. The mechanism of how $\mathrm{Zn}$ excess can cause toxicity is still unknown and is likely to be different to that caused by $\mathrm{Zn}$ deficiency.

Reduced cell viability was shown in Zn-depleted cells as measured via MTT assay and this is supported by an increase in both apoptotic and necrotic cells, observed via the CBMN-Cyt assay. Low cellular Zn concentration was found to induce programmed cell death in various cell types including fibroblasts, hepatocytes, T-cell precursors, glioma and testicular cells (Ho and Ames 2002; Ho et al. 2003; Yan et al. 2008; Bao and Knoell 2006; Yamaguchi et al. 2009). In addition, $\mathrm{Zn}$ depletion has also been associated with caspase activation and increases in apoptosis in airway epithelial cells, lung and hepatocytes (Truong-Tran et al. 2001; Hennig et al. 1999). Under low Zn conditions, Caspase 3 was reported to be involved in apoptosis induction via the intrinsic cell death pathway (Clegg et al. 2005). Our data confirmed that Zn-depleted cells caused an increase in the activation of Caspase 3 , in parallel with a higher percentage of apoptotic cells as measured via the CBMN-Cyt assay. Previous literature has shown that $\mathrm{ZnC}$ 
has a strong cytoprotective effect that might be due to the synergistic effect of $\mathrm{Zn}$ and L-carnosine (Nishida et al. 2010; Omatsu et al. 2010). However, there was no difference for the effect of the 2 different $\mathrm{Zn}$ forms when 2-way ANOVA analysis was performed.

In this study, we used both the comet assay and CBMNCyt assay to obtain more comprehensive data on how zinc affects genome stability. The alkaline comet assay provides a measure of single and double strand breaks in DNA and alkaline-labile abasic sites that are induced but remain unrepaired. In contrast, micronuclei and nucleoplasmic bridges may occur due to mis-repair of DNA strand breaks which leads to the formation of acentric chromosome fragments and dicentric chromosomes (Fenech 2007). An increase in DNA strand breaks was found in $\mathrm{Zn}$-depleted cells, which is consistent with previous studies (Ho and Ames 2002; Ho et al. 2003; Yan et al. 2008; Song et al. 2009a; Song et al. 2009b; Song et al. 2009c; Sharif et al. 2011). Higher concentrations of $\mathrm{Zn}$ further reduced DNA strand breaks ( 4 and $16 \mu \mathrm{M}$ ), but at the highest concentration tested $(32 \mu \mathrm{M})$, an increase in DNA strand breaks was observed suggesting a potential genotoxic effect for both $\mathrm{Zn}$ compounds when present in excess; however, this increase may have also been affected by a contribution of damaged DNA in necrotic cells which tended to increase at $32 \mu \mathrm{M} \mathrm{Zn}$. However, the mechanism by which $\mathrm{Zn}$ excess can cause toxicity remains unclear. Zn-depleted cells also showed higher expression of $\gamma-\mathrm{H} 2 \mathrm{AX}$ which is a sensitive molecular marker for DNA strand breaks (Mah et al. 2010). These results further confirmed the hypothesis that low $\mathrm{Zn}$ can cause genome instability via an increase in DNA strand breaks.

In the CBMN-Cyt assay, Zn-depleted cells expressed a higher frequency of MNi, NPBs and NBuds, while Znsupplemented cells showed significant reductions in DNA damage events $(P<0.05)$. To date, this is the first cytogenetic study to investigate the effects of various concentrations of $\mathrm{Zn}$ on $\mathrm{MNi}$, NPBs and NBuds expression simultaneously in HOK cells. The first study using the micronucleus assay, reported in 2001, showed that $\mathrm{Zn}$ dimethyl and $\mathrm{Zn}$ diisonyldithiocarbamate at 1.53, 15.3 and 153.3 $\mu \mathrm{M}$ did not induce any $\mathrm{MNi}$ in human peripheral blood lymphocyte culture (Zenzen et al. 2001). In contrast, Santra et al. (2002) showed that induction of MNi in $\mathrm{Zn}$ chloride-treated human lymphocytes at 0.15 and $0.3 \mathrm{mM}$ is significant compared with negative controls, but this did not occur in a dose-dependent manner (Santra et al. 2002). In our recent study, it was found that concentrations of $\mathrm{Zn}$ at 4 and $16 \mu \mathrm{M}$ reduce DNA damage events in WIL2-NS lymphoblastoid cell line relative to lower or higher concentrations (Sharif et al. 2011). This suggests that a narrow physiological range of $\mathrm{Zn}$ between 4 and $16 \mu \mathrm{M}$ is required for optimising chromosomal stability. Another previous investigation conducted in vivo found excess $\mathrm{Zn}$ acetate can induce significant increases in both $\mathrm{MNi}$ and sister chromatid exchange in bone marrow cells in an Algerian mouse model (Tapisso et al. 2009).

Several mechanisms that could lead to MN formation include simultaneous excision repair of damaged (e.g. 8-oxo-deoxyguanosine) or inappropriate bases (e.g. uracil) incorporated into DNA that are in close proximity and on opposite complementary DNA strands (Fenech et al. 2010). Such simultaneous repair events will lead to DNA double strand breaks and MN formation (Fenech and Crott 2002; Bull and Fenech 2008). In addition, hypomethylation of cytosine in centromeric and pericentromeric repeat sequences can also lead to $\mathrm{MN}$ formation (Fenech et al. 2010). There are very few studies that have investigated the relationship between $\mathrm{Zn}$ and hypomethylation. However, in one of the previous studies, $\mathrm{Zn}$ deficiency was found to reduce the utilisation of methyl groups from SAM in rat liver, resulting in genomic DNA hypomethylation and histone hypomethylation (Duerre and Wallwork 1986; Wallwork and Duerre 1985). This could lead to an increase in $\mathrm{MN}$ formation in $\mathrm{Zn}$-depleted cells, as observed in the present study due to whole chromosome loss and malsegregation caused by altered structure of pericentromeric DNA and failure of kinetechore assembly at centromeres (Fenech et al. 2011).

In the current study, it was also found that $\mathrm{Zn}$ depletion caused an increase in NPBs which may be due to DNA break mis-repair or telomere end fusion, possibly caused by accelerated telomere shortening or deletion and/or base damage in the telomere sequence (Murnane 2006). Telomere stability has been extensively correlated with the risk of cancer (Callen and Surralles 2004; Engelhardt et al. 1997; Griffith et al. 1999; Meeker 2006; Plentz et al. 2003; Sieglova et al. 2004), and few studies have investigated the relationship of $\mathrm{Zn}$ with telomere stability (Nemoto et al. 2000; Bae et al. 2007; Liu et al. 2004). Accumulation of cells with short telomeres, which may lead to telomere end fusions, was found to be associated with reduced $\mathrm{Zn}$ status in hypertensive patients (Cipriano et al. 2009). Human Tankyrase 1 (TANK1) that plays a key role in maintaining telomere integrity has a Zn-binding domain in its catalytic site and is therefore dependent on $\mathrm{Zn}$ for its function (Lehtio et al. 2008). TANK1 is a member of the growing family of (poly ADP-ribose) polymerases (PARPs) that interacts with ADP-ribosylases the telomere-binding protein TRF1 (Smith et al. 1998). The role of TANK1 involves displacing TRF1 from telomeric DNA and suggests that TANK1 may be a positive regulator of telomere length in telomerase-expressing cells (Smith and de Lange 2000; van Steensel and de Lange 1997). It is plausible that optimal Zn concentrations may reduce genomic instability events and the risk of cancer possibly by enhancing telomere stability 
and limiting the incidence of telomere end fusions (Bull and Fenech 2008; Callen and Surralles 2004). This may lead to reduced formation of dicentric chromosomes that are expressed as NPBs (Fenech 2006).

An increase in DNA damage events in Zn-depleted cells may be due to compromised DNA repair functions. In this study, it was found that p53 expression is increased under low $\mathrm{Zn}$ conditions, which is consistent with other previous studies (Ho and Ames 2002; Ho et al. 2003; Song et al. 2009c; Yan et al. 2008). p53 is a Zn-finger transcription factor that regulates both G1 and G2 checkpoints and plays a crucial role in regulating DNA repair (Fanzo et al. 2002; Fanzo et al. 2001). It is plausible that low $\mathrm{Zn}$ may upregulate p53 levels via oxidative DNA damage and the induction of ATM kinase, which can be activated by cellular stress and can phosphorylate and stabilise p53 protein (Siliciano et al. 1997). Thus, Zn status can indirectly affect p53 protein levels, yet $\mathrm{Zn}$ is also an integral component of p53 at its Zn-finger domain. However, although p53 is activated, other previous studies have found that DNAbinding activity of p53 is impaired by zinc deficiency (Yan et al. 2008; Ho and Ames 2002; Song et al. 2009c). Therefore, p53 which plays the role as a transcription factor may also be dysfunctional when $\mathrm{Zn}$ is deficient and may cause activation for gene transcription of some DNA damage response genes to be compromised. Besides p53, we also assessed two other DNA damage response and repair proteins, PARP and OGG1.

$\mathrm{Zn}$ is an essential component for PARP-1, which binds via its $\mathrm{Zn}$ domain to DNA strand breaks thereby assisting in the recruitment of DNA repair complexes (Mazen et al. 1989). PARP was found to be increased in Zn-depleted cells and this is consistent with another in vivo study that investigated the effect of $\mathrm{Zn}$ deficiency in rats (Song et al. 2009c). The induction of PARP under $\mathrm{Zn}$ depletion conditions as observed in our study suggests the accumulation of DNA damage at the molecular level (Song et al. 2009c) which coincided with a higher frequency of MNi, NPB and NBuds and higher DNA strand breaks. A positive correlation between cellular poly(ADP-ribosyl)ation and $\mathrm{Zn}$ status in human peripheral blood mononuclear cells (Kunzmann et al. 2008) was reported, further indicating that $\mathrm{Zn}$ is required for PARP activity.

$\mathrm{Zn}$ is also part of OGG1, another $\mathrm{Zn}$-finger protein which is a DNA repair enzyme that is crucial in base excision repair by removing 8-hydroxy-2'-deoxyguanosine, one of the more prevalent oxidative DNA damage events (Boiteux and Radicella 2000). This current study showed that OGG1 expression is significantly increased in $\mathrm{Zn}$ depleted cells suggesting that oxidative stress is one of the mechanisms by which Zn deficiency may cause DNA damage. Song et al. (2009a, b, c) hypothesised that there may be a potential hierarchy of induction of $\mathrm{Zn}$-deficient response proteins when $\mathrm{Zn}$ concentration is sub-optimal (Song et al. 2009c), and our previous finding using WIL2NS cells is consistent with this hypothesis because OGG1 was highly expressed in low $\mathrm{Zn}$ but the expression of PARP was only slightly affected in the same conditions (Sharif et al. 2011). However, in this study, the increment in OGG1 and PARP expression in HOK cells in Zn-deficient medium relative to $4 \mu \mathrm{M} \mathrm{Zn}$ was not markedly different.

Besides the involvement of $\mathrm{Zn}$ in certain DNA damage responses and DNA repair protein function, an increase in oxidative stress may also contribute to DNA damage events. In this study, the levels of metallothionein (MT) expression were measured to test whether this is one of the possible induced mechanisms that may exert a genomeprotective effect (Ho 2004). Zn can modulate the expression of metallothionein that is involved in cellular defence against free radicals and oxidative stress (Dreosti 2001). Our results showed that $\mathrm{Zn}$-depleted cells have a lower MT expression indicating that MT is not involved in protecting against Zn deficiency-induced oxidative stress. Cells with low levels of MT are more susceptible to DNA damage and apoptotic death following exposure to stress stimuli, including oxidative stress, whereas prior induction of MT appears to offer cellular protection against oxidants (Chimienti et al. 2001; Jourdan et al. 2002; Dineley et al. 2003; Maret et al. 2002). These results suggest that DNA damaging effects of $\mathrm{Zn}$ deficiency may be exacerbated by lower MT concentration.

In conclusion, both $\mathrm{ZnSO}_{4}$ and $\mathrm{ZnC}$ were shown to provide optimal cell viability and minimal DNA damage at 4 and $16 \mu \mathrm{M} \mathrm{Zn}$ concentration. Higher concentrations of $\mathrm{Zn}(32$ and $100 \mu \mathrm{M})$ or $\mathrm{Zn}$ deficiency $(\leq 0.4 \mu \mathrm{M})$ may cause adverse cellular cytotoxic and genotoxic effects, respectively. Although mechanisms of how $\mathrm{Zn}$ deficiency can affect genome integrity is becoming clearer with the involvement of $\mathrm{Zn}$ in p53, PARP and OGG1, the mechanism by which $\mathrm{Zn}$ excess can cause toxicity is still unknown. It is evident that more attention should be given to $\mathrm{Zn}$ levels in culture medium which should be carefully maintained at an optimal concentration to maintain genome stability. Future studies should be aimed at determining whether observations for this cell type also apply to other human epithelial cells depending on their genotype for $\mathrm{Zn}$ transport, Zn metabolism, Zn-finger protein and enzymes that require $\mathrm{Zn}$ as a cofactor.

Acknowledgments The authors wish to thank Teresa Fowles, Lyndon Palmer (Waite Analytical Services, Adelaide) for their measurement of $\mathrm{Zn}$ in culture medium and cells. Rhys Hamon (Queen Elizabeth Hospital, Adelaide) is acknowledged for help in training RS to perform western blot analysis.

Conflict of interest None declared. 


\section{References}

Babizhayev MA, Seguin MC, Gueyne J, Evstigneeva RP, Ageyeva EA, Zheltukhina GA (1994) L-carnosine (beta-alanyl-L-histidine) and carcinine (beta-alanylhistamine) act as natural antioxidants with hydroxyl-radical-scavenging and lipid-peroxidase activities. Biochem J 304(Pt 2):509-516

Bae SN, Kim J, Lee YS, Kim JD, Kim MY, Park LO (2007) Cytotoxic effect of zinc-citrate compound on choriocarcinoma cell lines. Placenta 28(1):22-30

Bao S, Knoell DL (2006) Zinc modulates airway epithelium susceptibility to death receptor-mediated apoptosis. Am J Physiol 290(3):L433-L441

Boiteux S, Radicella JP (2000) The human OGG1 gene: structure, functions, and its implication in the process of carcinogenesis. Arch Biochem Biophys 377(1):1-8

Bull C, Fenech M (2008) Genome-health nutrigenomics and nutrigenetics: nutritional requirements or 'nutriomes' for chromosomal stability and telomere maintenance at the individual level. Proc Nutr Soc 67(2):146-156

Callen E, Surralles J (2004) Telomere dysfunction in genome instability syndromes. Mutat Res 567(1):85-104

Chan KM, Decker EA (1994) Endogenous skeletal muscle antioxidants. Critical reviews in food science and nutrition 34(4):403-426

Chan WK, Decker EA, Chow CK, Boissonneault GA (1994) Effect of dietary carnosine on plasma and tissue antioxidant concentrations and on lipid oxidation in rat skeletal muscle. Lipids 29(7):461-466

Chang KL, Hung TC, Hsieh BS, Chen YH, Chen TF, Cheng HL (2006) Zinc at pharmacologic concentrations affects cytokine expression and induces apoptosis of human peripheral blood mononuclear cells. Nutrition (Burbank, Los Angeles County, Calif) 22(5):465-474

Chimienti F, Jourdan E, Favier A, Seve M (2001) Zinc resistance impairs sensitivity to oxidative stress in HeLa cells: protection through metallothioneins expression. Free Radic Biol Med 31(10): 1179-1190

Cipriano C, Tesei S, Malavolta M, Giacconi R, Muti E, Costarelli L, Piacenza F, Pierpaoli S, Galeazzi R, Blasco M, Vera E, Canela A, Lattanzio F, Mocchegiani E (2009) Accumulation of cells with short telomeres is associated with impaired zinc homeostasis and inflammation in old hypertensive participants. J Gerontol 64(7):745-751

Clegg MS, Hanna LA, Niles BJ, Momma TY, Keen CL (2005) Zinc deficiency-induced cell death. IUBMB Life 57(10):661-669

Dineley KE, Votyakova TV, Reynolds IJ (2003) Zinc inhibition of cellular energy production: implications for mitochondria and neurodegeneration. J Neurochem 85(3):563-570

Dreosti IE (2001) Zinc and the gene. Mutat Res 475(1-2):161-167

Duerre JA, Wallwork JC (1986) Methionine metabolism in isolated perfused livers from rats fed on zinc-deficient and restricted diets. British J Nutr 56(2):395-405

Eastmond DA, Tucker JD (1989) Kinetochore localization in micronucleated cytokinesis-blocked Chinese hamster ovary cells: a new and rapid assay for identifying aneuploidy-inducing agents. Mutat Res 224(4):517-525

Engelhardt M, Drullinsky P, Guillem J, Moore MA (1997) Telomerase and telomere length in the development and progression of premalignant lesions to colorectal cancer. Clin Cancer Res 3(11):1931-1941

Fanzo JC, Reaves SK, Cui L, Zhu L, Wu JY, Wang YR, Lei KY (2001) Zinc status affects p53, gadd45, and c-fos expression and caspase-3 activity in human bronchial epithelial cells. Am J Physiol 281(3):C751-C757
Fanzo JC, Reaves SK, Cui L, Zhu L, Lei KY (2002) p53 protein and p21 mRNA levels and caspase-3 activity are altered by zinc status in aortic endothelial cells. Am J Physiol 283(2):C631C638

Fenech M (2006) Cytokinesis-block micronucleus assay evolves into a "cytome" assay of chromosomal instability, mitotic dysfunction and cell death. Mutat Res 600(1-2):58-66

Fenech M (2007) Cytokinesis-block micronucleus cytome assay. Nat Protoc 2(5):1084-1104

Fenech MF (2010) Dietary reference values of individual micronutrients and nutriomes for genome damage prevention: current status and a road map to the future. Am J Clin Nutr 91(5):1438S$1454 \mathrm{~S}$

Fenech M, Crott JW (2002) Micronuclei, nucleoplasmic bridges and nuclear buds induced in folic acid deficient human lymphocytesevidence for breakage-fusion-bridge cycles in the cytokinesisblock micronucleus assay. Mutat Res 504(1-2):131-136

Fenech M, Kirsch-Volders M, Natarajan AT, Surralles J, Crott JW, Parry J, Norppa H, Eastmond DA, Tucker JD, Thomas P (2010) Molecular mechanisms of micronucleus, nucleoplasmic bridge and nuclear bud formation in mammalian and human cells. Mutagenesis 26(1):125-132

Fenech M, Kirsch-Volders M, Natarajan AT, Surralles J, Crott JW, Parry J, Norppa H, Eastmond DA, Tucker JD, Thomas P (2011) Molecular mechanisms of micronucleus, nucleoplasmic bridge and nuclear bud formation in mammalian and human cells. Mutagenesis 26(1):125-132

Griffith JK, Bryant JE, Fordyce CA, Gilliland FD, Joste NE, Moyzis RK (1999) Reduced telomere DNA content is correlated with genomic instability and metastasis in invasive human breast carcinoma. Breast Cancer Res Treat 54(1):59-64

Hambidge M (2003) Biomarkers of trace mineral intake and status. J Nutr 133(3):948S-955S

Hennig B, Meerarani P, Ramadass P, Toborek M, Malecki A, Slim R, McClain CJ (1999) Zinc nutrition and apoptosis of vascular endothelial cells: implications in atherosclerosis. Nutr (Burbank, Los Angeles County, Calif) 15(10):744-748

Hipkiss AR (1998) Carnosine, a protective, anti-ageing peptide? Int J Biochem Cell Biol 30(8):863-868

Hipkiss AR, Chana H (1998) Carnosine protects proteins against methylglyoxal-mediated modifications. Biochem Biophys Res Commun 248(1):28-32

Hipkiss AR, Preston JE, Himswoth DT, Worthington VC, Abbot NJ (1997) Protective effects of carnosine against malondialdehydeinduced toxicity towards cultured rat brain endothelial cells. Neurosci Lett 238(3):135-138

Hipkiss AR, Worthington VC, Himsworth DT, Herwig W (1998) Protective effects of carnosine against protein modification mediated by malondialdehyde and hypochlorite. Biochim Biophys Acta 1380(1):46-54

Ho E (2004) Zinc deficiency, DNA damage and cancer risk. J Nutr biochem 15(10):572-578

Ho E, Ames BN (2002) Low intracellular zinc induces oxidative DNA damage, disrupts p53, NFkappa B, and AP1 DNA binding, and affects DNA repair in a rat glioma cell line. Proc Natl Acad Sci USA 99(26):16770-16775

Ho E, Courtemanche C, Ames BN (2003) Zinc deficiency induces oxidative DNA damage and increases p53 expression in human lung fibroblasts. J Nutr 133(8):2543-2548

Jourdan E, Emonet-Piccardi N, Didier C, Beani JC, Favier A, Richard MJ (2002) Effects of cadmium and zinc on solar-simulated lightirradiated cells: potential role of zinc-metallothionein in zincinduced genoprotection. Arch Biochem Biophys 405(2):170-177

Klebanov GI, Teselkin Yu O, Babenkova IV, Lyubitsky OB, Rebrova O, Boldyrev AA, Vladimirov Yu A (1998) Effect of carnosine 
and its components on free-radical reactions. Membr Cell biol 12(1):89-99

Kunzmann A, Dedoussis G, Jajte J, Malavolta M, Mocchegiani E, Burkle A (2008) Effect of zinc on cellular poly(ADP-ribosyl)ation capacity. Exp Gerontol 43(5):409-414

Lehtio L, Collins R, van den Berg S, Johansson A, Dahlgren LG, Hammarstrom M, Helleday T, Holmberg-Schiavone L, Karlberg $\mathrm{T}$, Weigelt $\mathrm{J}$ (2008) Zinc binding catalytic domain of human tankyrase 1. J Mol Biol 379(1):136-145

Li N, Sun Z, Liu Z, Han C (1998) Study on the preventive effect of tea on DNA damage of the buccal mucosa cells in oral leukoplakias induce by cigarette smoking. Wei Sheng Yan Jiu 27(3):173-174

Liu Q, Wang H, Hu D, Ding C, Xu H, Tao D (2004) Effects of trace elements on the telomere lengths of hepatocytes L-02 and hepatoma cells SMMC-7721. Biol Trace Elem Res 100(3): 215-227

Lundqvist C, Baranov V, Teglund S, Hammarstrom S, Hammarstrom ML (1994) Cytokine profile and ultrastructure of intraepithelial gamma delta $\mathrm{T}$ cells in chronically inflamed human gingiva suggest a cytotoxic effector function. J Immunol 153(5):23022312

Mah LJ, El-Osta A, Karagiannis TC (2010) GammaH2AX: a sensitive molecular marker of DNA damage and repair. Leukemia 24(4):679-686

Mahmood A, FitzGerald AJ, Marchbank T, Ntatsaki E, Murray D, Ghosh S, Playford RJ (2007) Zinc carnosine, a health food supplement that stabilises small bowel integrity and stimulates gut repair processes. Gut 56(2):168-175

Maret W, Heffron G, Hill HA, Djuricic D, Jiang LJ, Vallee BL (2002) The ATP/metallothionein interaction: NMR and STM. Biochemistry 41(5):1689-1694

Mazen A, Menissier-de Murcia J, Molinete M, Simonin F, Gradwohl G, Poirier G, de Murcia G (1989) Poly(ADP-ribose)polymerase: a novel finger protein. Nucleic Acids Res 17(12):4689-4698

Meeker AK (2006) Telomeres and telomerase in prostatic intraepithelial neoplasia and prostate cancer biology. Urol Oncol 24(2):122-130

Mitchell C, Joyce AR, Piper JT, McKallip RJ, Fariss MW (2010) Role of oxidative stress and MAPK signaling in reference moist smokeless tobacco-induced HOK-16B cell death. Toxicol Lett 195(1):23-30

Mosmann T (1983) Rapid colorimetric assay for cellular growth and survival: application to proliferation and cytotoxicity assays. J Immunol Methods 65(1-2):55-63

Munoz N, Hayashi M, Bang LJ, Wahrendorf J, Crespi M, Bosch FX (1987) Effect of riboflavin, retinol, and zinc on micronuclei of buccal mucosa and of esophagus: a randomized double-blind intervention study in China. J Natl Cancer Inst 79(4):687-691

Murgia C, Lang CJ, Truong-Tran AQ, Grosser D, Jayaram L, Ruffin RE, Perozzi G, Zalewski PD (2006) Zinc and its specific transporters as potential targets in airway disease. Curr Drug Targ 7(5):607-627

Murnane JP (2006) Telomeres and chromosome instability. DNA Repair 5(9-10): 1082-1092

Nemoto K, Kondo Y, Himeno S, Suzuki Y, Hara S, Akimoto M, Imura N (2000) Modulation of telomerase activity by zinc in human prostatic and renal cancer cells. Biochem Pharmacol 59(4):401-405

Nersesyan AK (2006) Does cigarette smoking induce micronuclei in buccal cells? Am J clin Nutr 84(4):946-947; author reply 947-948

Nersesyan AK, Adamyan RT (2004) Micronuclei level in exfoliated buccal mucosa cells of patients with benign and malignant tumors of female reproductive organs and breast. Tsitol Genet 38(3):72-75
Nersesyan A, Chobanyan N (2010) Micronuclei and other nuclear anomalies levels in exfoliated buccal cells and DNA damage in leukocytes of patients with polycystic ovary syndrome. J Buon 15(2):337-339

Nersesyan A, Muradyan R, Kundi M, Knasmueller S (2010) Impact of smoking on the frequencies of micronuclei and other nuclear abnormalities in exfoliated oral cells: a comparative study with different cigarette types. Mutagenesis

Nishida T, Ohata S, Kusumoto C, Mochida S, Nakada J, Inagaki Y, Ohta Y, Matsura T (2010) Zinc Supplementation with Polaprezinc Protects Mouse Hepatocytes against AcetaminophenInduced Toxicity via Induction of Heat Shock Protein 70. J Clin Biochem Nutr 46(1):43-51

Olive PL, Banath JP, Durand RE (1990) Heterogeneity in radiationinduced DNA damage and repair in tumor and normal cells measured using the "comet" assay. Radiat Res 122(1):86-94

Omatsu T, Naito Y, Handa O, Mizushima K, Hayashi N, Qin Y, Harusato A, Hirata I, Kishimoto E, Okada H, Uchiyama K, Ishikawa $\mathrm{T}$, Takagi $\mathrm{T}$, Yagi $\mathrm{N}$, Kokura $\mathrm{S}$, Ichikawa $\mathrm{H}$, Yoshikawa $\mathrm{T}$ (2010) Reactive oxygen species-quenching and anti-apoptotic effect of polaprezinc on indomethacin-induced small intestinal epithelial cell injury. $\mathbf{J}$ Gastroenterol 45(7):692-702

Phillips HJ (1973) Dye exclusion test for cell viability. In: Kruser PF (ed) Tissue culture. Academic Press, New York, pp 407-408

Piyathilake CJ, Macaluso M, Hine RJ, Vinter DW, Richards EW, Krumdieck CL (1995) Cigarette smoking, intracellular vitamin deficiency, and occurrence of micronuclei in epithelial cells of the buccal mucosa. Cancer Epidemiol Biomarkers Prev 4(7):751-758

Plentz RR, Wiemann SU, Flemming P, Meier PN, Kubicka S, Kreipe H, Manns MP, Rudolph KL (2003) Telomere shortening of epithelial cells characterises the adenoma-carcinoma transition of human colorectal cancer. Gut 52(9):1304-1307

Prasad MP, Mukundan MA, Krishnaswamy K (1995) Micronuclei and carcinogen DNA adducts as intermediate end points in nutrient intervention trial of precancerous lesions in the oral cavity. Eur J Cancer B Oral Oncol 31B(3):155-159

Presland RB, Dale BA (2000) Epithelial structural proteins of the skin and oral cavity: function in health and disease. Crit Rev Oral Biol Med 11(4):383-408

Ramirez A, Saldanha PH (2002) Micronucleus investigation of alcoholic patients with oral carcinomas. Genet Mol Res 1(3):246-260

Rouabhia M, Ross G, Page N, Chakir J (2002) Interleukin-18 and gamma interferon production by oral epithelial cells in response to exposure to Candida albicans or lipopolysaccharide stimulation. Infect Immun 70(12):7073-7080

Santra M, Das SK, Talukder G, Sharma A (2002) Induction of micronuclei by zinc in human leukocytes: a study using cytokinesis-block micronucleus assay. Biol Trace Elem Res 88(2):139-144

Sharif R, Thomas P, Zalewski P, Graham RD, Fenech M (2011) The effect of zinc sulphate and zinc carnosine on genome stability and cytotoxicity in the WIL2-NS human lymphoblastoid cell line. Mutat Res 720(1-2):22-33

Sieglova Z, Zilovcova S, Cermak J, Rihova H, Brezinova D, Dvorakova R, Markova M, Maaloufova J, Sajdova J, Brezinova J, Zemanova Z, Michalova K (2004) Dynamics of telomere erosion and its association with genome instability in myelodysplastic syndromes (MDS) and acute myelogenous leukemia arising from MDS: a marker of disease prognosis? Leukemia Res 28(10):1013-1021

Siliciano JD, Canman CE, Taya Y, Sakaguchi K, Appella E, Kastan MB (1997) DNA damage induces phosphorylation of the amino terminus of p53. Genes Dev 11(24):3471-3481 
Singh NP, McCoy MT, Tice RR, Schneider EL (1988) A simple technique for quantitation of low levels of DNA damage in individual cells. Exp Cell Res 175(1):184-191

Sliwinski T, Czechowska A, Kolodziejczak M, Jajte J, WisniewskaJarosinska M, Blasiak J (2009) Zinc salts differentially modulate DNA damage in normal and cancer cells. Cell Biol Int 33(4):542-547

Smith S, de Lange T (2000) Tankyrase promotes telomere elongation in human cells. Curr Biol 10(20):1299-1302

Smith S, Giriat I, Schmitt A, de Lange T (1998) Tankyrase, a poly(ADP-ribose) polymerase at human telomeres. Science (New York, NY 282(5393):1484-1487

Song Y, Chung CS, Bruno RS, Traber MG, Brown KH, King JC, Ho E (2009a) Dietary zinc restriction and repletion affects DNA integrity in healthy men. Am J Clin Nutr 90(2):321-328

Song Y, Elias V, Loban A, Scrimgeour AG, Ho E (2009b) Marginal zinc deficiency increases oxidative DNA damage in the prostate after chronic exercise. Free Radic Biol Med

Song Y, Leonard SW, Traber MG, Ho E (2009c) Zinc deficiency affects DNA damage, oxidative stress, antioxidant defenses, and DNA repair in rats. J Nutr 139(9):1626-1631

Tapisso JT, Marques CC, Mathias Mda L, Ramalhinho Mda G (2009) Induction of micronuclei and sister chromatid exchange in bonemarrow cells and abnormalities in sperm of Algerian mice (Mus spretus) exposed to cadmium, lead and zinc. Mutat Res 678(1):59-64

Thomas P, Wu J, Dhillon V, Fenech M (2010) Effect of dietary intervention on human micronucleus frequency in lymphocytes and buccal cells. Mutagenesis 26(1):69-76
Tice RR, Agurell E, Anderson D, Burlinson B, Hartmann A, Kobayashi H, Miyamae Y, Rojas E, Ryu JC, Sasaki YF (2000) Single cell gel/comet assay: guidelines for in vitro and in vivo genetic toxicology testing. Environ Mol Mutagen 35(3):206-221

Truong-Tran AQ, Carter J, Ruffin R, Zalewski PD (2001) New insights into the role of zinc in the respiratory epithelium. Immunol Cell Biol 79(2):170-177

van Steensel B, de Lange T (1997) Control of telomere length by the human telomeric protein TRF1. Nature 385(6618):740-743

Verbanac D, Milin C, Domitrovic R, Giacometti J, Pantovic R, Ciganj Z (1997) Determination of standard zinc values in the intact tissues of mice by ICP spectrometry. Biol Trace Elem Res 57(1):91-96

Wallwork JC, Duerre JA (1985) Effect of zinc deficiency on methionine metabolism, methylation reactions and protein synthesis in isolated perfused rat liver. J Nutr 115(2):252-262

Yamaguchi S, Miura C, Kikuchi K, Celino FT, Agusa T, Tanabe S, Miura T (2009) Zinc is an essential trace element for spermatogenesis. Proc Natl Acad Sci USA 106(26):10859-10864

Yan M, Song Y, Wong CP, Hardin K, Ho E (2008) Zinc deficiency alters DNA damage response genes in normal human prostate epithelial cells. J Nutr 138(4):667-673

Zenzen V, Fauth E, Zankl H, Janzowski C, Eisenbrand G (2001) Mutagenic and cytotoxic effectiveness of zinc dimethyl and zinc diisononyldithiocarbamate in human lymphocyte cultures. Mutat Res 497(1-2):89-99 